\title{
Chapter 12 \\ Knowledge Transfers Through Diaspora Transnationalism and Return Migration: A Case Study of Indian Skilled Migrants
}

\author{
Gabriela Tejada
}

\section{Introduction}

The current interest in academic research and policy discussions on the positive relationship between international skilled migration and development contrasts with the negative nationalist perspective of earlier brain drain/brain gain debates. These debates depicted skilled emigration as a definitive loss, and saw repatriation or compensation as the only way to balance the loss for countries of origin (Bhagwati 1976; Borjas 1987; Johnson 1967). More recently, new paradigms have emphasized the actual and potential positive impacts that skilled human capital can generate for countries of origin, with migrants contributing remotely through diverse channels of engagement such as knowledge and skills transfers, investment flows and entrepreneurial ventures, social and financial remittances, and diaspora networks (Agunias and Newland 2012; Boyle and Kitchin 2014; Kuznetsov 2013). Concurrent with this paradigm shift, return migration has attracted growing interest and is now seen as an important channel from which countries of origin can benefit. Return migration can potentially be a feedback effect of skilled migration because it can generate positive change in society, create employment and raise local productivity (Black and King 2004; Cassarino 2004; Dustman et al. 2011; King 2000).

Recent advances in thinking about international skilled migration have focused attention on the movement of human capital as a potential force for development (Docquier and Rapoport 2012; IOM 2013; OECD 2013a; Özden et al. 2011). The mobility of professionals between firms and countries has increasingly been recognized as a powerful source of knowledge transfer, of both technology and more subtle gains such as business practices and networks of contacts (Regets 2001). Within this "brain gain" approach, two main issues emerge. First, skilled migrants

\footnotetext{
G. Tejada $(\triangle)$

Ecole polytechnique fédérale de Lausanne, Lausanne, Switzerland

e-mail: gabriela.tejada@epfl.ch
} 
in host countries can remotely generate positive effects through knowledge transfers involving diaspora networks, business and entrepreneurial ventures, social and financial remittances, and scientific and academic collaborations. All have the potential to benefit home country communities and strengthen the transnational nature of migration (Portes 2001, 2003; Vertovec 2004). Second, if skilled migrants decide to return to their country of origin, they bring with them accumulated knowledge and technical skills which can be transferred to the local context. Skills losses are thus potentially offset by the knowledge and expertise return migrants transfer back with them (Dustman et al. 2011; Iredale et al. 2003; Kapur and McHale 2005; King 1986, 2000; Kumar et al. 2014). At the same time, the ability of migrants to transfer knowledge and skills is affected by contextual and structural determinants, institutional policies and how these skills are utilized in the local context (CODEV et al. 2013; Tejada et al. 2014a).

Transnationalism has become a widely used analytical framework in recent studies on international migration. The transnational lens recognizes the rise of diasporas or migrant communities as new actors in development processes. In this view, skilled migrants arguably possess multiple affiliations and attachments to host and home countries (Glick-Schiller et al. 1992; Levitt and Glick-Schiller 2004; Portes 2001, 2003; Vertovec 2004). They are also seen as carriers of knowledge, skills and social capital, which the home countries can benefit from (Meyer 2001; Tejada 2012). For sending states, the possibility of establishing long-distance connections with overseas-based skilled migrants offers an alternative to the strategy of promoting physical return. Migrants are no longer simply regarded as holders of human capital that needs to be recuperated, but rather as facilitators of knowledge transfer from abroad (Kumar et al. 2014; Tejada 2012). The social practices and relations that link migrants to their countries of origin could either be a response to their affective capital and long-distance obligations and a conscious identification with those countries, or they might just be part of their ordinary life without any attachment to a sense of belonging or affiliation (Levitt 2001; Levitt and Glick-Schiller 2004).

India is a country that has arguably profited from the positive outcomes of skilled migration (Kapur 2010; Kapur and McHale 2005). Early studies of the effects of skilled migration from India emphasized the effects of human capital loss and the negative cost of public investment in higher education (Bhagwati 1976; Johnson 1967). More recent studies have focused on the benefits to India generated through financial remittances and flows of migrants' savings to the home country (Afram 2012; Guha 2011; Rajan 2012). Attention has now shifted to other types of beneficial outcomes resulting from transfers of knowledge, technical skills, expertise and social capital accrued by skilled Indians during their time abroad. Empirical evidence shows how Indian skilled professionals in the IT sector and the software industry have been involved in various forms of diaspora transnationalism, helping innovation and entrepreneurship ventures in the software industry and the IT sector in India (Kapur 2002, 2010; Nanda and Khanna 2010; Saxenian 2005; 2006). Foreign-based skilled Indians have been depicted as a transnational class of professionals influencing the economic progress of India and its integration into the world economy (Kapur 2010; Kapur and McHale 2005). 
New research on the experiences of skilled Indians in their destination countries shows that their level of engagement with India is affected by individual characteristics as well as the structural and institutional context of the countries concerned (CODEV et al. 2013; Tejada et al. 2014a). At the individual level, socio-demographic characteristics, educational background and position in the host country are all influential factors. More generally, the living and working conditions in the host countries, the environments they are exposed to, and the opportunities offered in both the host country and in India significantly influence their ability to mobilize and engage in home country development.

Return migration represents another significant example of development leverage because it brings a human capital gain that might not have occurred had the migrants never left India (Regets 2001). Research into return migration has increased in recent years, with return skilled migration viewed as potentially beneficial for countries of origin due to the knowledge and skills that migrants bring back with them (Dustman et al. 2011; Iredale et al. 2003; Kapur and McHale 2005; King 1986, 2000; Kumar et al. 2014). Whether or how returnees have a development impact are questions often raised in the literature. Various empirical studies have observed that the individual migrant profile and patterns of migration, together with the socioeconomic conditions and structural environment in the home country, determine the level of overseas knowledge and expertise shared on return (Black et al. 2003; Iredale et al. 2003; Siddiqui and Tejada 2014). Other influential factors include migrants' sector and type of professional activity, and the match between their qualifications and the labour market requirements in the home country (Biswas 2014; Chacko 2007; CODEV et al. 2013; Gmelch 1980; King 1986, 2000; Kumar et al. 2014). Furthermore, returnee contributions depend on the context of return (Cassarino 2004; De Haas 2008; Iredale et al. 2003; Kumar et al. 2014). The specific location that migrants return to is an important determining factor. CODEV et al. (2013) show that although Indian returnees might have greater impact in rural areas, their location preferences are guided by the better infrastructure and employment prospects available in urban areas. Thus adequate infrastructure and business and entrepreneurial supports enhance the capacity of return migrants to apply the skills and resources they have gained during their time abroad (Ammassari 2003; Black et al. 2003; Wiesbrock 2008). The receptiveness of community and work colleagues to new ideas is another important factor (Black et al. 2003; Black and King 2004; Gmelch 1980). A recent study on Indian returnee entrepreneurs shows that while they have the potential to transfer the technical and specialized expertise accumulated overseas, they struggle to deploy the soft skills acquired abroad including managerial know-how and professional culture (Biswas 2014).

The Indian government has recently started to acknowledge the value of skilled migrants' accumulated resources by implementing a number of initiatives intended to engage with the Indian diaspora and encourage return migration (Bharte and Sharma 2014; Elie et al. 2011; Khadria 2009, 2012). Against this background, this chapter examines the obstacles and enablers that influence migrant knowledge transfer through diaspora transnationalism and return migration in the Indian context. The chapter adopts a two-fold approach, focusing both on countries of origin and 
countries of destination, and offers an empirical analysis of the main determinants and outcomes of actual and potential Indian skilled migrant knowledge and skills transfer. Skilled migration is seen here as encompassing both labour migration and third-level studies (tertiary education or education beyond high school) undertaken abroad. In addition to pursuing professional opportunities abroad, more and more Indians are emigrating as students. The two categories are often interconnected; for example, many people join the labour market in the destination country after completing their degree overseas, while others work and study at the same time.

The chapter is based on new empirical data collected through primary surveys and in-depth interviews with Indian skilled migrants in Europe and with returnees in India. The study found that Indian skilled professionals, scientists and students are contributing to their home country while they are abroad and after they return. These contributions are manifested in various channels of engagement including financial remittances and investments, social capital, knowledge transfer through diaspora interventions and physical return. The study focused on knowledge transfer through diaspora transnationalism and physical return to the home country. The chapter highlights the development aspirations of skilled Indians in Europe and illustrates the transnational actions they engage in to transfer knowledge and promote positive linkages. While Indian skilled professionals, students and researchers in Europe link their development aspirations to their return plans, and believe that Indian society can benefit from the knowledge and expertise they accumulate overseas, the reality is that they are faced with several obstacles within the local system in India. They also encounter difficulties when transferring the specialized knowledge and technical skills gained abroad after they return.

The chapter begins with a brief overview of the literature on the development impact of Indian skilled migration. Existing research into skilled migration from India is extensive and calls attention to the contributions of diaspora transnationalism and return migration (CODEV et al. 2013; Tejada et al. 2014a). This section is followed by a discussion of the relevance of the Indian case in terms of skilled migration and diasporic knowledge transfers. The discussion shows that the structural position and social embeddedness of Indian diasporas and returnees have increased the flow of ideas and have increasingly played a role in reshaping India's socio-economic policies (Kapur 2004). The chapter then presents the results of the study of Indian skilled migrants in order to understand the prevailing factors that influence their knowledge transfer efforts. The final section offers some specific policy recommendations for India.

\section{Indian Skilled Migration}

\section{Skilled Migration from India to Europe}

India has been a leading emigration country for the last two centuries. In mid-2013 it accounted for migrant stocks overseas of no fewer than 14 million (UN-DESA and OECD 2013). Moreover, Indians now represent the world's second largest 
diaspora community after China, with an estimated migrant population around the 25 million mark, which includes both Non-Resident Indians (NRIs) and foreign Persons of Indian Origin (PIOs) distributed among 189 countries (Khadria 2007; MOIA 2012). Recent Indian emigration includes important flows of unskilled and semi-skilled workers to the Gulf countries in west Asia and the Middle East. Most skilled workers seek opportunities in North America, Europe and Australia where they are employed in the IT, engineering and health care sectors (Chanda and Sreenivasan 2006; Khadria 2007).

While the emigration of skilled Indians to industrialized countries has increased since the 1970s, a significant number of Indian IT professionals and engineers emigrated to North America and Europe during the 1990s. In recent years, industrialized countries in continental Europe have emerged as new destinations as a result of their transformation into knowledge-based economies and their participation in the global competition for talent (Buga and Meyer 2012; Mosneaga 2014). As part of the trend towards the selection of immigrants, particularly those with more skills, migration policies have been adapted to increase the stock of global talent, improve national competitiveness and compensate for skill shortages in specific economic sectors. The supply of Indian skilled labour to continental Europe is especially notable in IT, engineering, finance and management, pharmaceuticals, and the academic and research sectors (Brücker et al. 2012; CODEV et al. 2013; Tejada et al. 2014b; Wiesbrock and Hercog 2012).

In 2008, Indian nationals ranked third among non-EU immigrant flows to the EU-27 region with 93,000 arrivals, after Morocco and China. Data on stocks indicate that $2 \%(512,000)$ of the total foreign population in the EU-27 region hailed from India (European Commission 2014). Moreover, UN-DESA and OECD (2013) estimates show that $60 \%$ (or 2 million) out of a total of 3.4 million Indians living in OECD countries in 2011 had tertiary level education. This figure makes India the leading source of skilled migrants in OECD countries among developing countries, ahead of both China and the Philippines (with 1.7 million and 1.4 million respectively). Taken together, these three countries accounted for $20 \%$ of all tertiary educated immigrants in OECD countries in 2010/2011 (UN-DESA and OECD 2013).

\section{International Flows of Indian Students}

The remarkable growth of international student migration from India is increasingly well-documented (OECD 2013a). As Khadria (2007) points out, the "academic gate" now represents a significant and particular set of actors amongst Indian skilled migrants. International exposure and overseas experience, including the opportunity to study abroad, are highly valued in India as part of the prevalent view that a foreign degree ensures better employment prospects at home (Hercog and Van de Laar 2013a, b; Mukherjee and Chanda 2012). Indian student migration has become more conspicuous in European destination countries as these countries adapt their labour migration policies to recruit those who are seen as providing the greatest economic benefit (OECD 2013a). Many European countries have adopted policies to 
encourage international graduates to remain after their studies and work. For example, in Switzerland and France, international students are allowed to stay in the country for up to 6 months after completing their studies to look for employment, whilst in the Netherlands and Germany stays of up to 12 and 18 months respectively are permitted (OECD 2013a; CODEV et al. 2013; Tejada et al. 2014b).

India now ranks second worldwide after China as the main source country of international students. The UNESCO Institute of Statistics (2014) registered a substantial increase in the share of Indian students in the last decade, rising from $3 \%$ in 2000 (53,000 students) to $5.6 \%$ in 2010 (200,000 students). The share of Indian students among all foreign students enrolled in tertiary education in OECD countries rose from $4 \%$ in 2001 to $6.5 \%$ in 2011, with Indians becoming the second main group of international students from non-OECD countries, surpassed only by the Chinese (at $21 \%$ ) (OECD 2013b). While the main traditional destinations of Indian students are North America, the UK and Australia, increasing numbers have been moving in recent years to continental European nations such as Germany, France, the Netherlands, Switzerland and Denmark. The deficiencies of the Indian education system, in terms of coverage and quality, means that the opportunity to get an overseas education is restricted to a tiny group of privileged people, or what Amartya Sen refers to as "the first boys" (Drèze and Sen 2013; Sen 2005). As Sen (2005) points out, the Indian education regime lavishes attention on privileged students and overlooks general education, thereby undermining India's development. This situation mirrors the broad social divisions in India where basic capabilities are unequally distributed by society and the state (Sen 2005: 10). Such inequities are part of a broader problem of economic and social inequality related to class, caste, gender and social privilege.

\section{Scientific Infrastructure in India and Collaboration with Europe}

A number of studies have shown how an adequate local scientific and technological infrastructure in the country of origin impacts on the level of knowledge and technology transfer possible from returned skilled migrants (Barré et al. 2003; CODEV et al. 2013; Kuznetsov 2013; Tejada et al. 2013). India is a major participant in global knowledge production within the science and technology fields and in terms of international scientific collaborations. According to the Indian National Institute of Science, Technology and Development, the country is the tenth most productive in terms of the number of scientific publications, with a global publication share of $2.32 \%$ between 1996 and 2010 (Mehra and Pohit 2013). India's share of global publications rose from $1.89 \%$ between 1996 and 2000 to $2.78 \%$ between 2006 and 2010, and it moved from 13th to 10th in the global publication ranking during the same period (Mehra and Pohit 2013). The areas with the highest scientific research publications output include the physical sciences, engineering sciences, life sciences and health sciences. Among non-OECD countries India ranked third $(2.11 \%)$ 
after China $(6.50 \%)$ and Russia $(2.33 \%)$ in 2008 in the world production of scientific publications (Banerjee 2009).

With regard to cooperation in science and technology between Europe and India, the strategies that various European countries have implemented in recent years show how promoting bilateral collaboration with India has become a top priority. Various principles have shaped the implementation of such strategies. First, cooperation with India is seen as a win-win endeavour based on the formation of partnerships between equals. Second, human capital mobility should ideally benefit both India and the receiving countries, through the implementation of provisions that stimulate the exchange and circulation of students and researchers in both directions. Third, institutional provisions such as bilateral scientific programmes which promote collaboration in a complementary manner should ensure the pairing of research work with high-level international partners, and create mutual benefits for researchers and their institutions in both India and Europe (Bolay and Tejada 2014). Top-down incentive mechanisms, such as bilateral institutional programmes, as well as bottom-up transnational collaboration initiatives, driven by skilled Indians themselves, are important for encouraging knowledge transfer through cooperation and other forms of interactions that India can benefit from. However, an adequate host country environment is important with regard to effectively exploiting knowledge and skills from both the diaspora and from returnees.

\section{Skilled Migrants and Indian Development}

The rest of the chapter draws on a study of the experiences of Indian skilled migrants in Europe and their engagement in knowledge transfer with India. The data was collected in 2011 and 2012 using two survey questionnaires administered simultaneously in India and in Europe. By conducting research in both India and Europe, the study provided an opportunity to simultaneously observe the development impact on India of return skilled migration and the activities and potential of skilled diasporas in destination countries (CODEV et al. 2013; Tejada et al. 2014a). The Indian part of the research focused on skilled Indian returnees in six major cities in India: the Delhi-National Capital region, Kolkata, Hyderabad, Bangalore, Mumbai and Pune. The definition of "Indian return skilled migrant" used for the study was a past or present NRI or PIO who had stayed abroad for more than 6 months before returning to India, who was employed in India and who had at least a bachelor's degree. The European part of the research interviewed Indian students and skilled professionals who were first generation migrants living in four European countries: France, Germany, the Netherlands and Switzerland. These destination countries were selected on the strength of the growing number of Indian skilled professionals and students moving there.

Since there is no database in India that shows the total number of returnees to India and no reliable list of Indians living abroad, purposive and snowball sampling 
techniques were used for data collection both in India and in Europe. The samples comprise 527 returnees in India and 835 Indian students and skilled professionals in the selected European destination countries. Because of their limited size, the samples are not representative of the entire Indian skilled migrant and return population. In addition, a total of 30 qualitative in-depth interviews were conducted to complement the survey analysis. Interviews in the countries of destination included 10 Indian professionals (10 interviews) and 7 postgraduate students ( 7 interviews). Six return migrants were interviewed in India. Additional interviews were also held in both Europe and India with 7 experts with specialist knowledge of international mobility between India and Europe.

\section{Diaspora Engagement in Knowledge Transfer}

The study showed that the desire of skilled Indian migrants to contribute to the development of India is quite strong, independent of their activity profiles (whether professionals working in the private sector, scientists and researchers working in academia, or students). Of the sample of Indian students and skilled professionals in Europe, $77 \%$ considered development in India to be very important to them, while $20 \%$ considered it to be somewhat important (Fig. 12.1). Only $1 \%$ said it was of no importance to them.

Although any knowledge accumulated by migrants could potentially benefit the home country, it is not easy to measure the actual impact objectively. The Indian migrants in Europe were asked if they thought that their present activity could have an impact on socio-economic development in India, a question designed to understand skilled migrants' perceptions of the extent of their potential influence on the country. As many as $70 \%$ of the respondents felt that their present activity could have an impact on the socio-economic development of India (Table 12.1). The $30 \%$ who did not gave two main reasons. First, the nature of their activities did not

Fig. 12.1 Skilled Indians' interest in India's development

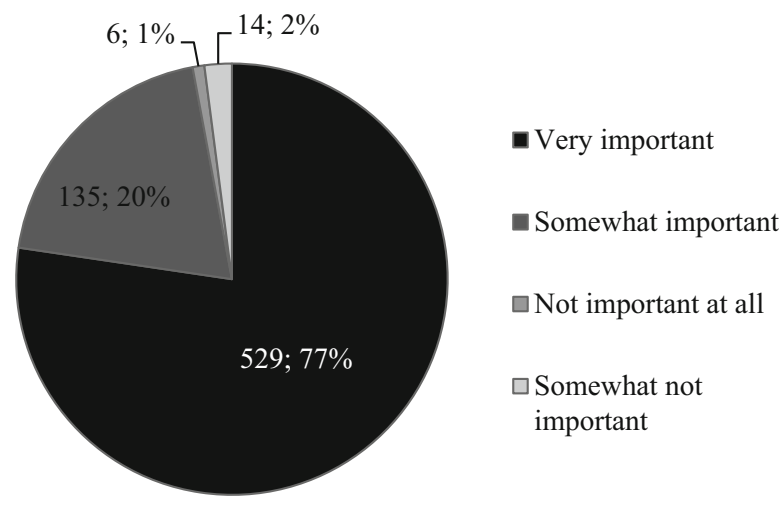


Table 12.1 Perception of whether current activity could impact on India's development

\begin{tabular}{l|l|l|r}
\hline Activity: & Yes (\%) & No $(\%)$ & $\mathrm{N}$ \\
\hline In employment $^{\prime}$ & 64.4 & 35.7 & 216 \\
\hline In training and education $^{\mathrm{a}}$ & 74.8 & 25.2 & 405 \\
\hline Other $^{\mathrm{b}}$ & 61.3 & 38.7 & 75 \\
\hline Total & 70.1 & 29.9 & 696 \\
\hline
\end{tabular}

Source: Field survey in Europe, 2011-2012

ancludes persons on internships, MBA and $\mathrm{PhD}$ students as well as students with jobs

${ }^{b}$ Includes people involved in housework, self-employed, retired and unemployed people

provide any value for deployment in India, or had very little to do with the social realities of the Indian context. Second, they were reluctant to engage in any development action towards India because of various disappointing factors such as the political situation, the lengthy bureaucracy or the limited infrastructure. As one stated, "my present activity would not help in the development of India because it is too high-end research, and anyway the infrastructure does not exist. The red tape to establish it is excessive and I am not interested in trying to combat that."

Skilled Indians in training and education had more positive feelings about the likelihood of influencing India's development than professionals in paid employment (Table 12.1). The fact that more students believe that their accumulated education and skills could have a direct socio-economic effect in India may be a consequence of their emotional ties with the country. Also, students' younger age might result in greater concern and interest in their home country. However, student intentions and motivations may not be backed up with concrete actions because they may lack resources, whereas professionals in paid employment may be able to count on the support of social and intellectual networks, as well as the infrastructure and resources necessary to back their development intentions. This may indicate that life cycle optimism matters in terms of intentions while factual employment and established career matter in terms of execution. Also, as "semi-finished human capital" (Khadria 2003), students are still shaping their professional identities so they are not fully formed in terms of knowing how they can contribute with their skills and expertise.

Individual attributes certainly influence the development aspirations of Indian skilled migrants (Siddiqui and Tejada 2014; Tejada and Siddiqui 2014). A higher propensity and willingness to engage in India's development process is associated with disadvantaged identities related to gender, caste and religion. Skilled migrant women, Dalits and Muslims, in particular, have stronger development aspirations linked to a motivation to mitigate social inequality in India. This is a consequence of the comparisons they make between their experience of social disparity in India and the freedom and rights enjoyed abroad. Other factors that influence the motivation and aspirations of skilled migrants to use their foreign-acquired knowledge and skills for the benefit of India include their education, age and length of stay abroad. The higher the level of education, the greater the age and the longer the stay abroad, the greater their interest in home country development (Siddiqui and Tejada 2014; Tejada and Siddiqui 2014). 
Skilled Indian migrants' development aspirations are also linked to their return plans. Those involved in academia and research in the destination countries believe that Indian society can benefit from their scientific networks and expertise. One $\mathrm{PhD}$ student in Switzerland, for example, noted that, "I want to return to India with all that I have gained during my studies here and give back the good part of education system here to India. I will use the experience and scientific contacts I made here for research back there". A postdoctoral researcher based in Germany observed that "if I go back and do this research in India, it could potentially help more students in my field to have a good exposure. Especially those brilliant ones who cannot afford to go out".

Migrants often strategically invest their resources and time in activities that are relevant to their private and professional future plans, including their future mobility plans. Whereas migrants used to send money back to their countries of origin as a form of social insurance (Amuedo-Dorantes and Pozo 2006), analogous behaviour can be anticipated from non-economic activities. In fact, if they intend to return to their home country, they are likely to attach greater importance to maintaining and strengthening ties with relatives, colleagues and acquaintances left behind. In turn, these preparations for return tend to have a greater development impact because, in the process, they mobilize resources to improve their chances for a successful return (Cassarino 2004). As Portes (2001) argues, transnational actions and links - such as the exchange of knowledge and ideas, regular visits to the home country and the transfer of financial remittances - ease migrants' re-adaptation to local society after they return and their access to information regulates the pace of adaptation (Sabates-Wheeler et al. 2009).

The evidence from skilled Indians living in Europe is that their transnational ties with India include knowledge transfer through a variety of practices. Skilled Indians in Europe believe in the possibility of being able to contribute from abroad through scientific cooperation and knowledge transfer, for example. As one Indian researcher said, "I am developing research collaborations with Indian scientists, which can help in technology transfer and knowledge sharing". Another said that "I can influence India from here in the form of direct contribution through scientific knowledge and technology transfer and by helping to educate and train young professionals". The personal, professional and scientific connections they maintain with their colleagues and community in India are mainly motivated by two goals: first, establishing collaborations of several types; and second, preparing for their future return. In other words, skilled Indians' transnational engagement is a dynamic process, expressing individual life plans, social expectations and professional prospects (Hercog and Tejada 2013).

Establishing collaborations in the form of scientific and academic exchanges with colleagues and the community left behind is a common form of knowledge transfer by skilled Indians in Europe (Tejada and Bolay 2010). Skilled Indian migrants are used to maintaining their ties with their former colleagues in India while they are abroad, and in some cases these contacts intensify over time. Through these connections, skilled Indians facilitate access to their own networks by their peers based in India. As providers of accumulated social capital, the benefits of 
networks are indisputable. A skilled Indian returnee working at Indian Institute of Technology (IIT) Delhi put it this way, "Networking is always beneficial and equally important, whether it is Germany or India; the more you network, the more types of collaborations you have". In similar vein, a lecturer at the Bose Institute in Kolkata noted that, "students who go abroad and stay there keep in touch. I have had strong collaborations with some of them. We keep writing papers together".

\section{Knowledge and Skills Transfer Upon Return}

The majority of skilled Indian returnees interviewed for this study in India viewed their overseas experience as having an important effect on their personal development. They also believed that they had acquired attributes that could be usefully deployed in the local context to create benefits for their workplace and society at large. Amongst the benefits of overseas experience, knowledge and skills emerged as the most important in their current occupation. These were followed by hands-on experience and the networks established overseas. The financial capital accumulated overseas as well as their foreign qualifications were regarded as only of slight value (Fig. 12.2).

Respondents in the Indian survey were asked to give specific examples of how they used the skills, experience, knowledge and ideas they had gained overseas to contribute to their current company, institution or business. Compelling evidence of knowledge transfer emerged in the systematic communication between European and Indian professionals on various issues significant for India's development. The more explicit means by which skilled Indians said they apply their overseas skills and expertise included teaching and training, research and development, and changes in the work culture and environment (Fig. 12.3).

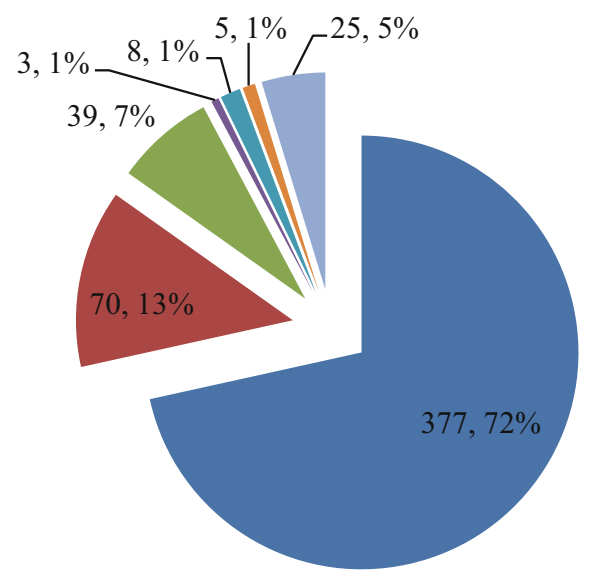

Knowledge and skills
gained overseas
$\square$ Hands on experience
abroad
Network established
overseas
Capital accumulated
overseas
Foreign qualification
$\square$ Others
No Answer

Fig. 12.2 Value of overseas experience to current occupation in India 


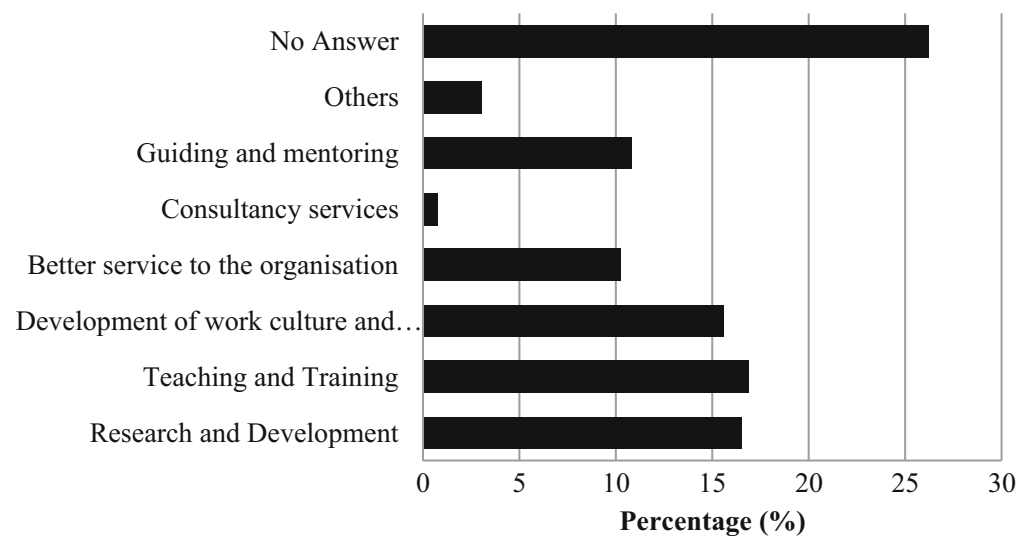

Fig. 12.3 Returnees' use of skills, experience and knowledge gained overseas

The deployment of foreign-earned skills partially depends on the employment sector of returnees. For example, those in the research and academic sector said they apply their overseas skills and competencies in activities related to R\&D or training. Those professionally employed in technical positions said they mainly apply them in the development of a work culture and environment that is more progressive, as well as in providing better services to their organization. The majority, independent to their sector of employment, thought that they were able to transfer their knowledge or expertise effectively in their work place. However, some returnees said they face obstacles in sharing and transferring their knowledge and expertise locally, such as resistance to change in the work culture, lack of suitable infrastructure and lengthy bureaucratic processes, all of which affect their efficiency at work. The contributions of return migrants are also heavily affected by the adjustment capabilities of the returnees and the structural support provided by the local institutional context.

\section{Conclusion}

The impact that skilled migration has on development as a result of knowledge transfer occurs through two main channels of engagement: diaspora transnationalism and physical return to the home country. Diaspora knowledge transfer strengthens the transnational nature of migration and has important implications for countries of origin. India represents a good example of this because of the strong presence of Indian skilled professionals and students in industrialized countries. The case of India shows how skilled professionals and students can transfer knowledge and expertise and compensate their home country for skills outflows while they are abroad, as well as after they return.

This study of skilled Indians in Europe offers evidence of two main types of factors influencing skilled migrants' transnational engagements: individual and con- 
textual factors. On the one hand, individual factors, such as socio-demographic profile, educational background, and the activity and position in the host country, are all important variables. On the other, the living and working conditions in the host countries, the environments they are exposed to, and the opportunities offered in both the host and the home countries are significant factors influencing skilled migrants' ability to engage in home country development. Top-down incentive mechanisms such as bilateral institutional programmes, as well as bottom-up transnational collaboration initiatives driven by skilled Indian migrants themselves, are important in terms of encouraging knowledge transfer through cooperation and other forms of interaction. While the motivation to contribute to India's development is strong among the great majority of Indian skilled migrants, a stronger tendency for participation is associated with disadvantaged identities related to gender, caste and religion.

The development aspirations of Indian skilled migrants are linked to their return plans, and may materialize in actual return. As carriers of knowledge, innovative skills and suitable attitudes towards creativity, skilled migrant returnees frequently ease the transfer of knowledge and skills and encourage a work culture that is suitable for development. Skilled Indian returnees believe that Indian society can benefit from their accumulated resources and from their scientific and professional networks and expertise. However, knowledge transfer may not take place simply because someone returns, as returnees may not be able to convert their technical and specialized expertise due to local contextual and workplace barriers. While the majority of returnees have been able to transfer their knowledge or expertise to their work place, some faced important obstacles that limited such transfers.

Significant changes to India's workplace culture and structure are clearly necessary to facilitate and enable knowledge and expertise transfer from skilled migrants and translate it into development. If skilled migrants' expectations about their contribution are not satisfied, they could feel disillusioned, which may undermine their transnational connections or provoke eventual remigration. If this is the case, a receptive attitude both from the society at large and in the work place needs to be promoted. Institutional policies supporting effective diaspora and returnees' development engagement should be strengthened. While a number of measures have been put in place in recent years by the government of India in this direction, many remain unknown to Indian diaspora and returnees. Dissemination of the possible benefits generated from the transfer of skilled migrants' knowledge, scientific and professional competences, ideas and expertise in the local context could help to promote such policies.

Acknowledgements The study was carried out as part of the international research project "Migration, scientific diasporas and development: impact of skilled return migration on development in India," which was led by the Cooperation and Development Center (CODEV) of the École Polytechnique Fédérale de Lausanne (EPFL), and was implemented in collaboration with the Institute of Development Studies Kolkata (IDSK), the International Migration and Diaspora Studies (IMDS) Project of the Jawaharlal Nehru University (JNU) and the International Labour Office (ILO). The project was funded by the Swiss Network for International Studies (SNIS) in Switzerland. 


\section{References}

Afram, G. (2012). The remittance market in India: Opportunities, challenges and policy options. Washington, DC: World Bank.

Agunias, D., \& Newland, K. (2012). Developing a road map for engaging diasporas in development: A handbook for policymakers and practitioners in home and host countries. Geneva/ Washington, DC: IOM and Migration Policy Institute.

Ammassari, S. (2003). From nation-building to entrepreneurship: The impact of elite return migrants in Côte d'Ivoire and Ghana (Working Paper). Brighton: Sussex Centre for Migration Research, University of Sussex.

Amuedo-Dorantes, C., \& Pozo, S. (2006). Remittances as insurance: Evidence from Mexican immigrants. Journal of Population Economics, 19(2), 227-254.

Banerjee, P. (Ed.). (2009). India, science and technology 2008. New Delhi: NISTADS.

Barré, R., Hernández, V., Meyer, J.-B., \& Vinck, D. (2003). Diasporas scientifiques. Comment les pays en développement peuvent-ils tirer parti de leurs chercheurs et de leurs ingénieurs expatriés? Paris: Institute de la Recherche pour le Développement.

Bhagwati, J. (Ed.). (1976). The brain drain and taxation volume II: Theory and empirical analysis. Amsterdam: North Holland.

Bharte, U., \& Sharma, R. (2014). Diasporic paths to development: An Indian perspective. In G. Tejada, U. Bhattacharya, B. Khadria, \& C. Kuptsch (Eds.), Indian skilled migration and development: To Europe and back (pp. 161-184). New Delhi: Springer.

Biswas, R. (2014). Reverse migrant entrepreneurs in India: Motivations, trajectories and realities. In G. Tejada, U. Bhattacharya, B. Khadria, \& C. Kuptsch (Eds.), Indian skilled migration and development: To Europe and back (pp. 285-307). New Delhi: Springer.

Black, R., \& King, R. (2004). Editorial introduction: Migration, return and development in West Africa. Population, Space and Place, 10(2), 75-83.

Black, R., King, R., \& Tiemoko, R. (2003). Migration, return and small enterprise development in Ghana: A route out of poverty? Brighton: Sussex Centre for Migration Research, Sussex University.

Bolay, J.-C., \& Tejada, G. (2014). Globalization challenges and knowledge transfer from the Indian scientific diaspora. In G. Tejada, U. Bhattacharya, B. Khadria, \& C. Kuptsch (Eds.), Indian skilled migration and development: To Europe and back (pp. 185-211). New Delhi: Springer.

Borjas, G. (1987). Self-selection and the earnings of immigrants. American Economic Review, 77(4), 531-553.

Boyle, M., \& Kitchin, R. (2014). Diaspora-centered development: Current practice, critical commentaries, and research priorities. In S. Sahoo \& B. Pattanaik (Eds.), Global diasporas and development: Socio-economic, cultural, and policy perspectives (pp. 17-37). New Delhi: Springer.

Brücker, H., Bertoli, S., Facchini, G., Mayda, A. M., \& Peri, G. (2012). Understanding highly skilled migration in developed countries: The upcoming battle for brains. In T. Boeri, H. Brücker, F. Docquier, \& H. Rapoport (Eds.), Brain drain and brain gain: The global competition to attract high-skilled migrants (pp. 15-198). Oxford: Oxford University Press.

Buga, N., \& Meyer, J.-B. (2012). Indian human resources mobility: Brain drain versus brain gain (CARIM-India Research Report 2012/04). San Domenico di Fiesole: Robert Schuman Centre for Advanced Studies, European University Institute.

Cassarino, J.-P. (2004). Theorising return migration: The conceptual approach to return migrants revisited. International Journal on Multicultural Societies, 6(2), 253-279.

Chacko, E. (2007). From brain drain to brain gain: Reverse migration to Bangalore and Hyderabad, India's globalizing high tech cities. GeoJournal, 68(2/3), 131-140.

Chanda, R., \& Sreenivasan, N. (2006). India's experience with skilled migration. In C. Kuptsch \& E. Pang (Eds.), Competing for global talent (pp. 215-256). Geneva: ILO. 
CODEV-EPFL, IDSK, JNU, \& ILO. (2013). Migration, scientific diasporas and development: Impact of skilled return migration on development in India (Final research report). Cahier de la Cooperation no. 8. Lausanne: CODEV-EPFL.

De Haas, H. (2008). Migration and development: A theoretical perspective (Working Paper 9). Oxford: International Migration Institute, University of Oxford.

Docquier, F., \& Rapoport, H. (2012). Globalization, brain drain and development. Journal of Economic Literature, 50(3), 681-730.

Drèze, J., \& Sen, A. (2013). An uncertain glory. India and its contradictions. New Delhi: Penguin.

Dustmann, C., Itzhak, F., \& Weiss, Y. (2011). Return migration, human capital accumulation and the brain drain. Journal of Development Economics, 95(1), 58-67.

Elie, J., Lieber, M., \& Lutringer, C. (2011). Migration et développement: les politiques de la China et de l'Inde à l'égard de leurs communautés d'outre-mer. International Development Policy, 2(2011), 215-230.

European Commission. (2014). Eurostat. At http://ec.europa.eu/eurostat

Glick-Schiller, N., Basch, L., \& Szanton Blanc, C. (1992). Transnationalism: A new analytic framework for understanding migration. In N. Glick-Schiller, L. Basch, \& C. Blanc-Szanton (Eds.), Towards a transnational perspective on migration: Race, ethnicity, and nationalism reconsidered (pp. 1-24). New York: New York Academy of Sciences.

Gmelch, G. (1980). Return migration. Annual Review of Anthropology, 9, 135-159.

Guha, P. (2011). Measuring international remittances in India: Concepts and empirics (ProGlo Working Paper Series, Working Paper No. 1). Amsterdam: National Institute of Advanced Studies/University of Amsterdam.

Hercog, M., \& Tejada, G. (2013). Incorporation of skilled migrants in a host country: Insights from the study of skilled Indians in Switzerland (IMDS Working Paper). New Delhi: Zakir Husain Center for Educational Studies, Jawaharlal Nehru University.

Hercog, M., \& Van de Laar, M. (2013a). Determinants of international mobility decision: The case-study of India (UNU-MERIT Working Paper 067). Maastricht: UNU-MERIT.

Hercog, M., \& Van de Laar, M. (2013b). What's the best place for me? Location-choice for S\&E students in India (UNU-MERIT Working Paper 066). Maastricht: UNU-MERIT.

IOM. (2013). World migration report 2013. Geneva: IOM.

Iredale, R., Guo, F., \& Rozario, S. (2003). Return migration in the Asia Pacific. Cheltenham/ Northampton: Edward Elgar Publishing.

Johnson, H. (1967). Some economic aspects of brain drain. Pakistan Development Review, 7(3), 379-411.

Kapur, D. (2002). The causes and consequences of India's IT boom. India Review, 1(2), 91-110.

Kapur, D. (2004). Ideas and economic reform in India: The role of international migration and the Indian diaspora. India Review, 3(4), 364-384.

Kapur, D. (2010). Diaspora, development, and democracy: The domestic impact of international migration from India. Princeton/Oxford: Princeton University Press.

Kapur, D., \& McHale, J. (2005). Give us your best and brightest. The global hunt for talent and its impact on the developing world. Baltimore: Brookings Institution Press.

Khadria, B. (2003). Case study of the Indian scientific diaspora. In R. Barré, V. Hernández, J.-B. Meyer, \& D. Vinck (Eds.), Scientific diasporas: How can developing countries benefit from their expatriate scientists and engineers? Paris: Institute de la Recherche pour le Développement.

Khadria, B. (2007). India: Skilled migration to developed countries, labour migration to the Gulf. In S. Castles \& R. Delgado Wise (Eds.), Migration and development: Perspectives from the South (pp. 79-112). Geneva: IOM.

Khadria, B. (Ed.). (2009). Indian migration report 2009. Past, present and the future outlook. New Delhi: IMDS-JNU.

Khadria, B. (Ed.). (2012). Indian migration report. The Americas 2010-2011. New Delhi: Cambridge University Press. 
King, R. (1986). Return migration and regional economic development: An overview. In R. King (Ed.), Return migration and regional economic problems (pp. 1-37). London: Croom Helm.

King, R. (2000). Generalizations from the history of return migration. In B. Ghosh (Ed.), Return migration: Journey of hope or despair? (pp. 7-56). Geneva: IOM and United Nations.

Kumar, P., Bhattacharya, U., \& Nayek, J. (2014). Return migration and development: Evidence from India's skilled professionals. In G. Tejada, U. Bhattacharya, B. Khadria, \& C. Kuptsch (Eds.), Indian skilled migration and development: To Europe and back (pp. 263-284). New Delhi: Springer.

Kuznetsov, Y. (Ed.). (2013). How talent abroad can induce development at home? Towards a pragmatic diaspora agenda. Washington, DC: Migration Policy Institute.

Levitt, P. (2001). The transnational villagers. Berkeley: University of California Press.

Levitt, P., \& Glick-Schiller, N. (2004). Conceptualizing simultaneity: A transnational social field perspective on society. International Migration Review, 38(3), 1002-1039.

Mehra, K., \& Pohit, S. (Eds.). (2013). India. Science and technology (Vol. 2). New Delhi: Cambridge University Press.

Meyer, J. B. (2001). Network approach versus brain drain: Lessons from the diaspora. International Migration, 39(5), 91-110.

MOIA. (2012). Annual report 2011-12, Ministry of Overseas Indian Affairs. New Delhi: Government of India.

Mosneaga, A. (2014). Student migration at the global trijuncture of higher education, competition for talent and migration management. In G. Tejada, U. Bhattacharya, B. Khadria, \& C. Kuptsch (Eds.), Indian skilled migration and development: To Europe and back (pp. 87-111). New Delhi: Springer.

Mukherjee, S., \& Chanda, R. (2012). Indian student mobility to selected European countries: An overview (Working Paper 365). Bangalore: Indian Institute of Management.

Nanda, P., \& Khanna, T. (2010). Diasporas and domestic entrepreneurs: Evidence from the Indian software industry. Journal of Economics and Management Strategy, 19(4), 991-1012.

OECD. (2013a). International migration outlook 2013. Paris: OECD Publishing.

OECD. (2013b). Education at a glance 2013, OECD indicators. Paris: OECD Publishing.

Özden, C., Parsons, C., Schiff, M., \& Walmsley, T. L. (2011). Where on earth is everybody? The evolution of global bilateral migration 1960-2000. World Bank Economic Review, 25(1), $12-56$.

Portes, A. (2001). The debates and significance of immigrant transnationalism. Global Networks, 1(3), 181-194.

Portes, A. (2003). Conclusion: Theoretical convergencies and empirical evidence in the study of immigrant transnationalism. International Migration Review, 37(3), 874-892.

Rajan, I. (Ed.). (2012). India migration report 2012: Global financial crisis, migration and remittances. London: Routledge.

Regets, M. (2001). Research and policy issues in high-skilled international migration: A perspective with data from the United States (IZA Discussion Paper No. 366). Bonn: Forschungsinstitut zur Zukunft der Arbeit GmbH.

Sabates-Wheeler, R., Taylor, L., \& Natali, C. (2009). Great expectations and reality checks: The role of information in mediating migrants' experience on return. European Journal of Development Research, 21, 752-771.

Saxenian, A.-L. (2005). From brain drain to brain circulation: Transnational communities and regional upgrading in India and China. Studies in Comparative International Development, $40(2), 35-61$.

Saxenian, A. (2006). The new Argonauts. Regional advantage in a global economy. Cambridge: Harvard University Press.

Sen, A. (2005.) The country of first boys. The Little Magazine, VI(1\&2) 7-17.

Siddiqui, Z., \& Tejada, G. (2014). Development and highly skilled migrants: Perspectives from the Indian diaspora and returnees. International Development Policy, 6(1). 
Tejada, G. (2012). Mobility, knowledge and cooperation: Scientific diasporas as agents of development. Migration and Development, 10(18), 59-92.

Tejada, G., \& Bolay, J.-C. (Eds.). (2010). Scientific diasporas as development partners: Skilled migrants from Colombia, India and South Africa in Switzerland. Empirical evidence and policy responses. Bern: Peter Lang.

Tejada, G., \& Siddiqui, Z. (2014). Transferring skills upon return: Matching aspirations in the host countries with the reality back in India. In G. Tejada, U. Bhattacharya, B. Khadria, \& C. Kuptsch (Eds.), Indian skilled migration and development: To Europe and back (pp. 237-261). New Delhi: Springer.

Tejada, G., Varzari, V., \& Porcescu, S. (2013). Scientific diasporas, transnationalism and homecountry development: Evidence from a study of skilled Moldovans abroad. Journal of South East European and Black Sea Studies, 13(2), 157-173.

Tejada, G., Bhattacharya, U., Khadria, B., \& Kuptsch, C. (Eds.). (2014a). Indian skilled migration and development: To Europe and back. New Delhi: Springer.

Tejada, G., Herçog, M., Kuptsch, C., \& Bolay, J.-C. (2014b). The link with a home country: A comparative analysis of host country environments for diaspora engagement. In S. Sahoo \& B. Pattanaik (Eds.), Global diasporas and development: Socio-economic, cultural, and policy perspectives (pp. 39-68). New Delhi: Springer.

UN-DESA, \& OECD. (2013). World migration in figures. At: http://www.oecd.org/els/mig/WorldMigration-in-Figures.pdf

UNESCO. (2014). Global flow of tertiary-level students. Montreal: UNESCO Institute for Statistics (UIS).

Vertovec, S. (2004). Migrant transnationalism and modes of transformation. International Migration Review, 38(3), 970-1001.

Wiesbrock, A. (2008). Return migration as a tool for economic development in China and India (Working Paper 3). New Delhi: International Migration and Diasporas Study Project.

Wiesbrock, A., \& Hercog, M. (2012). Making Europe more attractive to Indian highly-skilled migrants?: The Blue Card directive and national law in Germany and the Netherlands (CARIM-India Research Report 2012/09). San Domenico di Fiesole: Robert Schuman Centre for Advanced Studies, European University Institute. 